\title{
Change of radionuclide bioavailability in conditions of swamping territories within the Chernobyl accident Exclusion Zone
}

\author{
D.I. Gudkov ${ }^{1}$, A.B. Nazarov ${ }^{2}$ and A.E. Kaglyan ${ }^{1}$ \\ ${ }^{1}$ Department of Radioecology, Institute of Hydrobiology of the NAS of Ukraine, Geroyev \\ Stalingrada Ave. 12, UA-04210 Kiev, Ukraine \\ ${ }^{2}$ State Specialised Scientific and Production Enterprise "Ecocentre" of the Ministry of \\ Emergency Situations of Ukraine, Shkol'naya Str. 6, UA-07270 Chernobyl, Ukraine
}

\begin{abstract}
Presented studies were carried out during 1997-2007 within Krasnensky flood-lands on the left bank of the Pripyat River, which is the most contaminated region of the Chernobyl accident exclusion zone and where the complex of hydraulic engineering structures as flood protection dams was constructed, which preventing washing away of radioactive substances from soils and changing a hydrological mode of floodplain flows during a high water. In its turn it was by the reason of strengthening of over-moistening and swamping processes within embankment territories. As a result - on a background of the common tendencies of increase of the mobile forms of ${ }^{90} \mathrm{Sr}$ in soils of catchment territories and bottom sediments of the exclusion zone, there is an increase of humic acids concentrations in waterlogged soils of Krasnensky flood-lands. It is also raises the content of the water-soluble forms of ${ }^{90} \mathrm{Sr}$ forming with acids the soluble complexes. Thus the increase of concentrations of the mobile radionuclide forms and their inclusion into biotic circulation of aquatic ecosystems is observed. Such dynamics of ${ }^{90} \mathrm{Sr}$ and ${ }^{137} \mathrm{Cs}$ contents is significantly reflected on dose rate for hydrobionts due to incorporated radionuclides.
\end{abstract}

\section{INTRODUCTION}

The basic problems of radiation safety of the Chernobyl accident Exclusion Zone are connected with radionuclide washout with surface run-off into the river systems, radioactivity carry-over beyond the bounds of the exclusion zone and sharing in formation of water quality of the Dnieper River - the main waterway of Ukraine. In this connection the radiation condition of surface water of the Exclusion Zone has huge importance. Krasnensky flood-lands on the left bank of the Pripyat River are the most contaminated region of the Exclusion Zone. During 1991-1993 the complex of hydraulic engineering structures as flood protection dams was constructed here, which preventing washing away of radioactive substances from soils and changing a hydrological mode of floodplain flows during a high water. In its turn it was by the reason of strengthening of over-moistening and swamping processes within embankment territories. As a result - on a background of the common tendencies of increase of the mobile forms of radionuclides in soils of catchment territories and bottom sediments of the Exclusion Zone, there is an increase of the water-soluble forms of ${ }^{90} \mathrm{Sr}$ in waterlogged soils of Krasnensky floodlands. Thus the increase of concentrations of the mobile radionuclide forms and their inclusion into biotic circulation of aquatic ecosystems is observed.

\section{MATERIALS AND METHODS}

The investigations were performed in the period of 1990-2007 within Krasnensky flood-lands. External gamma irradiation dose rate was measured by DKS-01 dosimeter and by Na-I field radiometer SRP-68-03. The ${ }^{137} \mathrm{Cs}$ content was measured by $\gamma$-spectrometry complex: PGT IGC-25 detector 
(France), "Nokia LP 4900 B" analyser ("Nokia", Finland), low-volt feeding source - crate NIM BIN, amplifier NU-8210 ("Elektronicus Merokeszulekek Gyara", Hungary) and $100 \mathrm{~mm}$ thickness leaden protection. The ${ }^{90} \mathrm{Sr}$ content was measured on low-background NRR-610 $\beta$-radiometer (“Tesla”, Czech). The results were measured in $\mathrm{Bq} / \mathrm{kg}$ wet weight.

\section{RESULTS AND CONCLUSIONS}

Krasnensky flood-lands is characterised by variety of reservoirs, which are taking place at different stages of successional changes [1]. Among it meanders there are more 60 natural lakes and artificial (land-reclamation) reservoirs by the general area about $12 \mathrm{sq} . \mathrm{km}$. The basis of their vegetative cover is communities of higher aquatic plants (Fig. 1)

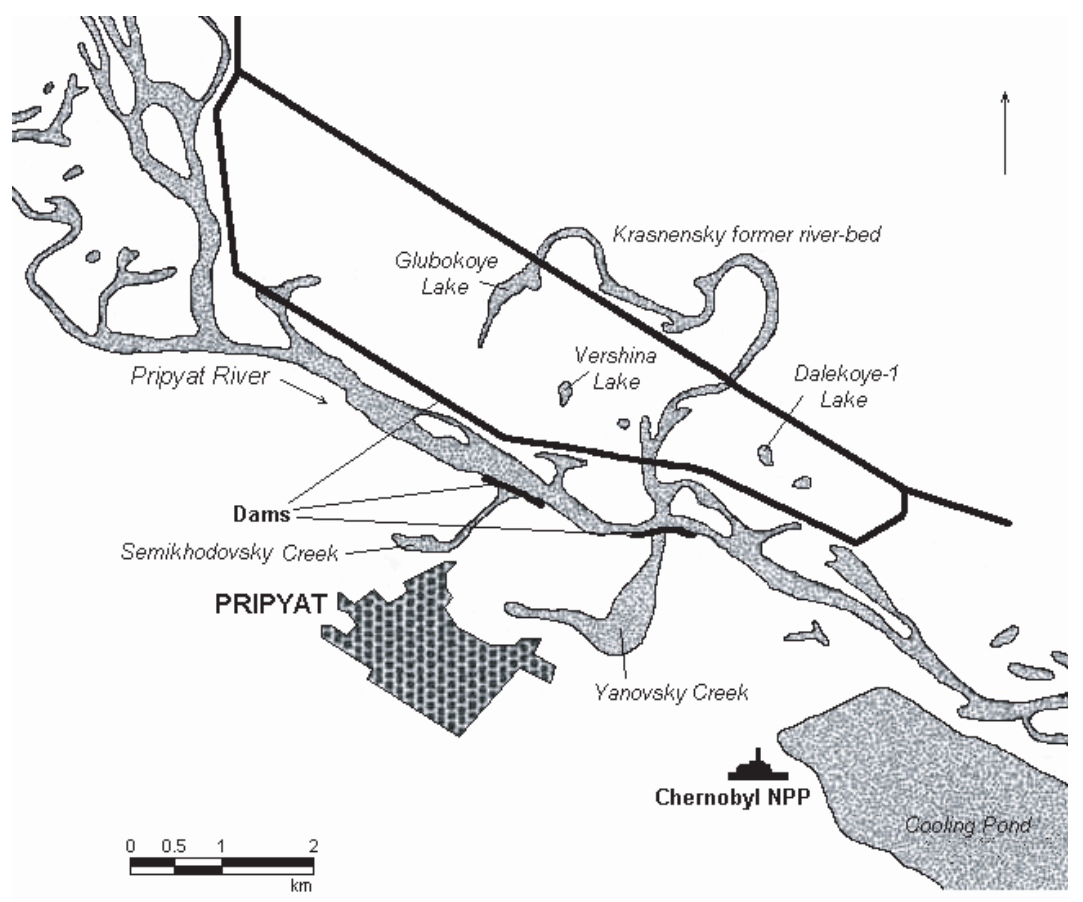

Figure 1. The map of dams and reservoirs of Krasnensky flood-lands within the inner $(10 \mathrm{~km})$ exclusion zone of the Chernobyl NPP.

For all water objects, studied since the early 1990-s, located within the Exclusion Zone, the general tendency in variations of radionuclide concentration in water of these objects is a decrease of ${ }^{90} \mathrm{Sr}$ and ${ }^{137} \mathrm{Cs}$ specific activity, which dynamics is firstly related to intensity of water exchange processes, with the only exclusion for closed water bodies of the left-bank flood-lands of the Pripyat River, located at the territory of dammed area of Krasnensky flood-lands (Glubokoe and Dalekoe-1 lakes), where recently, at the background of ${ }^{137} \mathrm{Cs}$ specific activity stabilization, a tendency to ${ }^{90} \mathrm{Sr}$ concentration increase was observed.

During the period of studies since 1990 till 2007, dynamics of the main radionuclide concentrations in tissues of the higher aquatic plants from river ecosystems of the exclusion zone indicated a decrease of specific activity of ${ }^{90} \mathrm{Sr}$ and ${ }^{137} \mathrm{Cs}$ (Fig. 2(a)). So far as concerns closed of low flowage water bodies, the most representative retrievals obtained in the period of 1993-2007 have shown that since the late 1990-s the higher aquatic plants related to different ecological groups is indicating a frank tendency to 
${ }^{90} \mathrm{Sr}$ content increase in tissues (Fig. 2(b)). The specific activity of ${ }^{137} \mathrm{Cs}$ in higher aquatic plants of the lakes under study either decreases or remains practically constant. Hence, in the middle 1990-s specific activity of ${ }^{137} \mathrm{Cs}$ in tissues of higher aquatic plants from Krasnensky flood plain was much higher than specific activity of ${ }^{90} \mathrm{Sr}$ in them, whereas in the late 1990 -s these values became comparable, and at present specific activity of ${ }^{90} \mathrm{Sr}$ is much higher than that of ${ }^{137} \mathrm{Cs}$.
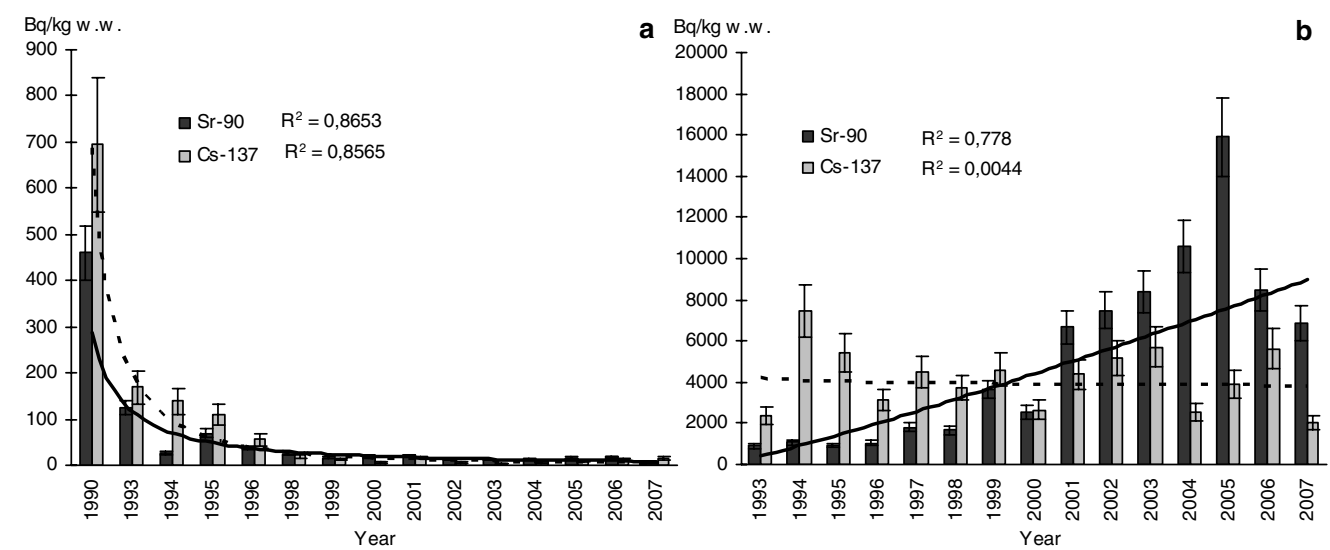

Figure 2. Dynamics of radionuclide content in higher aquatic plants of the Chernobyl Exclusion Zone: a - reedmace (Typha angustifolia L.) from the Pripyat River; b - water-soldier (Stratiotes aloides L.) from Glubokoe Lake. Here and on the Fig. 2. continuous line denotes ${ }^{90} \mathrm{Sr}$ specific activity trend; dashed line denotes ${ }^{137} \mathrm{Cs}$ specific activity trend.

During 1999-2007 the similar tendency was observed for predatory and prey fish from lakes located within Krasnensky flood-lands territory. If in 1999 the ratio of ${ }^{90} \mathrm{Sr}$ to ${ }^{137} \mathrm{Cs}$ in body of prey fish was about 0.2 , in 2000 this ratio has grown to 0.6, in $2001-2.0$ and in 2006 have reached 5.6 (Fig. 3).
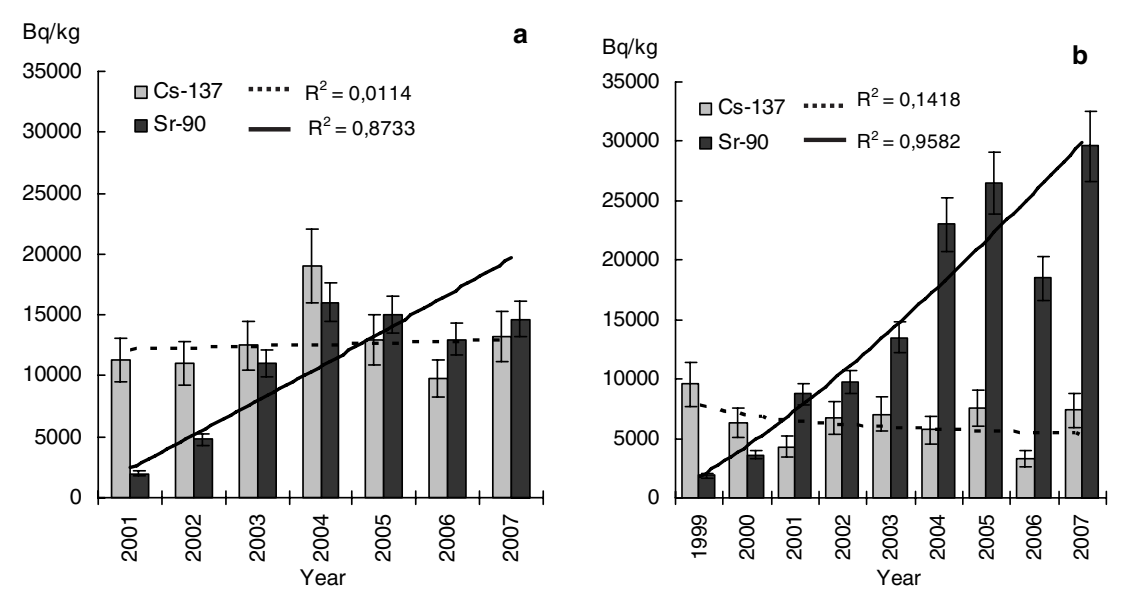

Figure 3. Dynamics of radionuclide content in predatory (a) and prey fish (b) from Glubokoe Lake.

It is suggested that ${ }^{90} \mathrm{Sr}$ specific activity in tissues of macrophytes and fish of Krasnensky flood plain increases due to dynamics of radionuclide transformation in soils of water catchments area and bottom sediments of water bodies. Due to construction a complex of flood control dams, which preventing 
radioactive substance washing off the soils of contaminated areas not only, but changed the hydrological regime of flood plain flows during floods, this became the reason for intensification of water-logging and swamping of dam-locked areas. This confirms the increase of a role of water-marsh floristic complex in structure of vegetative cover of Krasnensky flood-lands [2]. As a result of swamping, at the background of general tendencies of ${ }^{90} \mathrm{Sr}$ mobile form increase in the soils of water catchment areas and bottom sediments of the exclusion zone water bodies; in swamped soils of Krasnensky flood plain fulvic and humic acid concentration increases, that decreases $\mathrm{pH}$-value in water and intensifies a denuding of watersoluble forms of ${ }^{90} \mathrm{Sr}$ forming soluble complexes with fulvic acids. Hence, an increase of concentrations of mobile forms of the radionuclide and their inclusion to biotic turnover of aquatic ecosystems are observed. This also confirms the increase of ${ }^{90} \mathrm{Sr}$ specific activity, observed in recent years in Krasnensky flood plain lakes at the background of stabilization of this index for ${ }^{137} \mathrm{Cs}$.

The tendency of the root contamination of plant tissues by ${ }^{90} \mathrm{Sr}$ was also observed for terrestrial plants in the Exclusion Zone [3, 4]. Currently, some authors [5] suggest that ${ }^{90} \mathrm{Sr}$ mobility in soils of the exclusion zone is maximal, and this will last during the nearest decade. Thereafter, the rate of radionuclide decomposition will exceed the rate of its mobilization.

Such dynamics of ${ }^{90} \mathrm{Sr}$ and ${ }^{137} \mathrm{Cs}$ contents is significantly reflected on dose rate for hydrobionts due to incorporated radionuclides. However if in running water bodies the decrease of radionuclide contents defines, accordingly, and the decrease of dose rates, in lakes of the left-bank flood-lands of the Pripyat River the situation has an absolutely other character. At rather stable internal absorbed dose rate, caused by ${ }^{137} \mathrm{Cs}$ during $1993-2007$, the dose, caused by the ${ }^{90} \mathrm{Sr}$ content, has grown more than in 20 times for some species of higher aquatic plants and fish in comparison with the beginning of 1990-s (Fig. 4). As a result the total internal dose of plants and fish irradiation has increased more than in 6 times, that testifies to essential deterioration of radiating conditions for aquatic biota within territory of Krasnensky flood-lands.
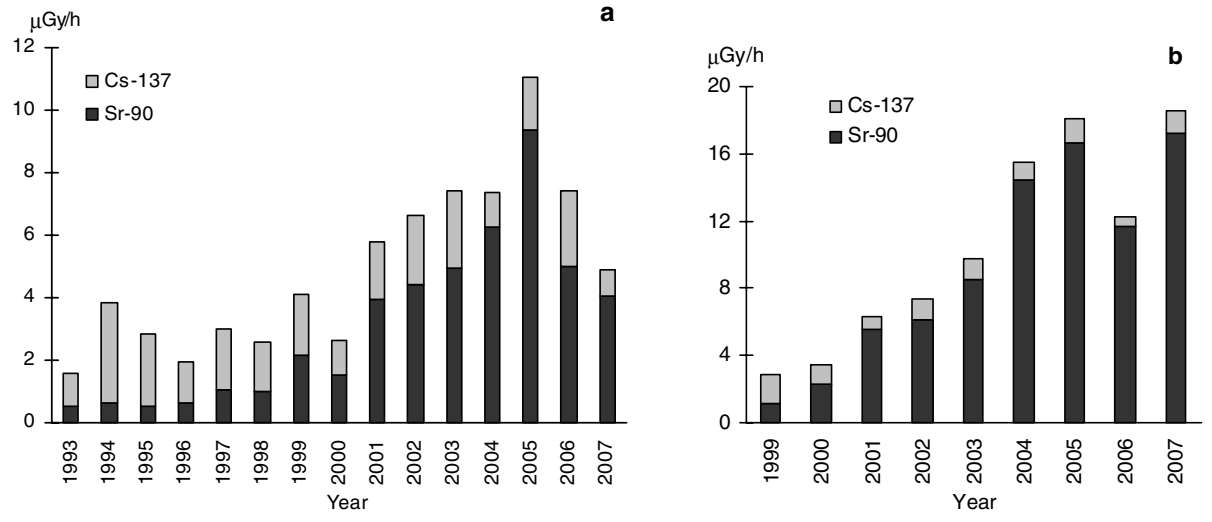

Figure 4. Dynamics of internal dose rate for the higher aquatic plan (Stratiotes aloides L.) (a) and prey fish (b) in Glubokoe Lake.

The results of tests performed confirm the tendency to further complication of the radiation situation in aquatic ecosystems of the Exclusion Zone. Swamping of contaminated territory leads to acceleration of ${ }^{90} \mathrm{Sr}$ deposited form mobilisation processes and their migration and redistribution in closed aquatic landscapes. Hence, an original "depot" of mobile forms of radioactive substances is formed, which in high-flood periods may become a source of increasing ${ }^{90} \mathrm{Sr}$ drainage to the Pripyat River and then outside the exclusion zone. In this connection, the necessity to implement hydraulic engineering procedures preventing underflooding of territories with high densities of radionuclide contamination; optimisation and enhancement of radioecological monitoring system, and further development of investigations 
of radionuclide behaviour in aquatic ecosystems of the Exclusion Zone - the important components in the complex of measures related to forecasting and minimisation of the Chernobyl accident consequences.

\section{Acknowledgments}

This study was supported by the Ministry on the Emergency of Ukraine and by the National Academy of Sciences of Ukraine as part of the state budgetary projects 0101U004987, 0102U004665. The authors also wish to thank the personnel of Radioanalytical Laboratory of the "Chernobyl Radioecological Centre" for the radionuclides measuring procedure.

\section{References}

[1] Gudkov, D.I., Zub, L.N., Savitsky, A.L., Nazarov, A.B. and Kaglyan, A.E., Hydrobilogical J. 5 (2002) 116-132.

[2] Gudkov, D.I., Zub, L.N. and Savitsky, A.L., Water Science and Technology 7 (2003) 89-96.

[3] Ivanov, Yu.A., Chernobyl - the Exclusion Zone (Naukova Dumka, Kiev, 2001) pp. 47-76 (Ukr).

[4] Kashparov, V.A., Bulletin of Ecological State of the Restriction Zone and the Zone of Compulsory (Mandatory) Evacuation 12 (1998) 67-74 (Ukr).

[5] Sobotovich, E.V., Bondarenko, G.N. and Kononenko, L.V. et al., Geochemistry of Production Induced Radionuclides (Naukova Dumka, Kiev, 2002) 332 p. (Rus). 
